\title{
HYALINEA MARMARICA, A NEW SPECIES OF BENTHIC FORAMINIFERA FROM THE SEA OF MARMARA (TURKEY)
}

\author{
Silvia SPEZZAFerRI ${ }^{1,3}$ AND VALENTINA YANKo-HombaCH ${ }^{2}$
}

\section{ABSTRACT}

Traditionally, the benthic foraminifera Hyalinea balthica (Schröter) has been considered a species with high intraspecific variability, possibly related to climatic changes, and, therefore, a potential indicator of paleoclimate in the Mediterranean Sea. However, a stable and characteristic morphology very different from the syntype of the species can be observed in specimens from the Sea of Marmara.

By identification and documentation of this morphology and a subsequent comparison to specimens similar to the type species, clear differences between the two groups have been established. Hyalinea marmarica n. sp. is proposed as an example of possible environment-related speciation in benthic foraminifera. It differs from $\boldsymbol{H}$. balthica in having less numerous chambers in the last whorl (maximum of eight), depressed sutures at least in the last four chambers, a moderate increase in chamber size as added, a subacute profile and accessory apertures on the peripheral margin.

Speciation could have occurred between 14 and $12 \mathrm{ka}$. At this time, increasingly efficient connections were progressively established between the Sea of Marmara and the Eastern Mediterranean Sea, allowing Hyalinea balthica to migrate into the Sea of Marmara. Here this species might have modified its morphology in response to the extreme environmental conditions.

\section{INTRODUCTION}

The Mediterranean Sea is a complex system subdivided into several basins, which are interconnected by straits and sills. It is presently considered a natural laboratory for studies of climate changes.

The Sea of Marmara is a gateway that connects the Aegean Sea to the west and the Black Sea to the northeast. Two relatively shallow straits, the Dardanelles (average water depth $75 \mathrm{~m}$ ) and the Bosporus (average water depth $45 \mathrm{~m}$ ), connect the Sea of Marmara to the Aegean and Black Seas, respectively.

Today, a two-way flow occurs between the Mediterranean and Black Seas through the Sea of Marmara. Brackish surface water flows from the Black Sea through the Sea of Marmara into the Mediterranean Sea, and saline deeper water flows from the Mediterranean Sea into the Sea of Marmara. Because of the existence of brackish outflow water from the Black Sea, a strong halocline is present in the Sea of Marmara, leading to low-oxygen conditions below the thin, well-mixed surface layer (Kaminski and others, 2002).

\footnotetext{
${ }^{1}$ University of Fribourg, Department of Geosciences, Geology and Paleontology, Chemin du Musée 6, 1700 Fribourg, Switzerland.

${ }^{2}$ Avalon Institute of Applied Science, Inc., Charleswood Technology Centre, 3227 Roblin Blvd, Winnipeg MB R3R 0C2, Canada.

${ }^{3}$ Correspondence author. E-mail: silvia.spezzaferri@unifr.ch
}

Benthic and planktonic foraminifera have been extensively used to study the impact of climate and environmental changes on these semi-enclosed basins (e.g., BlancVernet 1969; Cita and others, 1977; Vergnaud-Grazzini and others, 1977; de Rijk and others, 1999; Robertson and others, 1998; Comas and others, 1999; Ariztegui and others, 2000; Emeis and others, 2000). A species widely used in the Mediterranean Sea to reconstruct paleoclimatic changes is the benthic foraminifera Hyalinea balthica (Schröter), which is presently typical of cold, cool and cool-temperate environments (Bock, 1970; Murray, 1971; Hermelin, 1991) and which still lives in the Mediterranean Sea (Cita and others, 1977).

The ingression of this species into the Mediterranean Sea was used to mark the Plio-Pleistocene boundary (e.g., Gignoux, 1910; Emiliani and others, 1961; Flint, 1965; Selli, 1967) until it was demonstrated that the first appearance of Hyalinea balthica in this region is diachronous (e.g., Bremer and others, 1980; Lourens and others, 1998). Presently, the ingression of this species into the Mediterranean Sea is placed in proximity to the Santernian-Emilian substage boundary at $1.58 \mathrm{Ma}$ (Vaiani and Venezia, 1999; Vaiani, 2000).

The Pleistocene sedimentary sequence drilled at the Ocean Drilling Program (ODP) Hole 160-963A (Strait of Sicily, Eastern Mediterranean Sea) contains several intervals enriched with Hyalinea balthica, thus providing the opportunity to compare the different morphologies of this species. The European Union-funded project AVICENNE "Benthic foraminifera as indicators of heavy metal pollution-a new kind of biological monitoring for the Mediterranean Sea" provided the authors with living specimens of $H$. balthica (cruise AVI-I, Israeli coast). Additionally, several oceanographic campaigns in the Sea of Marmara provided the second author with cores and sediments for the study of this species. This article describes and compares different morphotypes of $H$. balthica, and the species Hyalinea marmarica n. sp. is proposed as an example of possible environment-related speciation in benthic foraminifera.

\section{MATERIALS AND METHODS}

Three sets of samples for this study were collected and prepared as follows. (1) ODP Hole 160-963A was drilled in the Strait of Sicily at a water depth of $470.5 \mathrm{~m}$ (Fig. 1). Samples from Hole 963A were soaked and washed in distilled water and dried at room temperature - no flotation techniques were employed. Dead assemblages were qualitatively studied in the $>63-\mu \mathrm{m}$ size fraction. (2) Three short cores were retrieved from the Sea of Marmara: Core BX2, BX3 and BX5 (Fig. 1, Table 1). The samples from the Sea of Marmara were recovered in 1988 by box corer during a cruise of the R/V Knorr. Cores were cut into 3-cm slabs, 


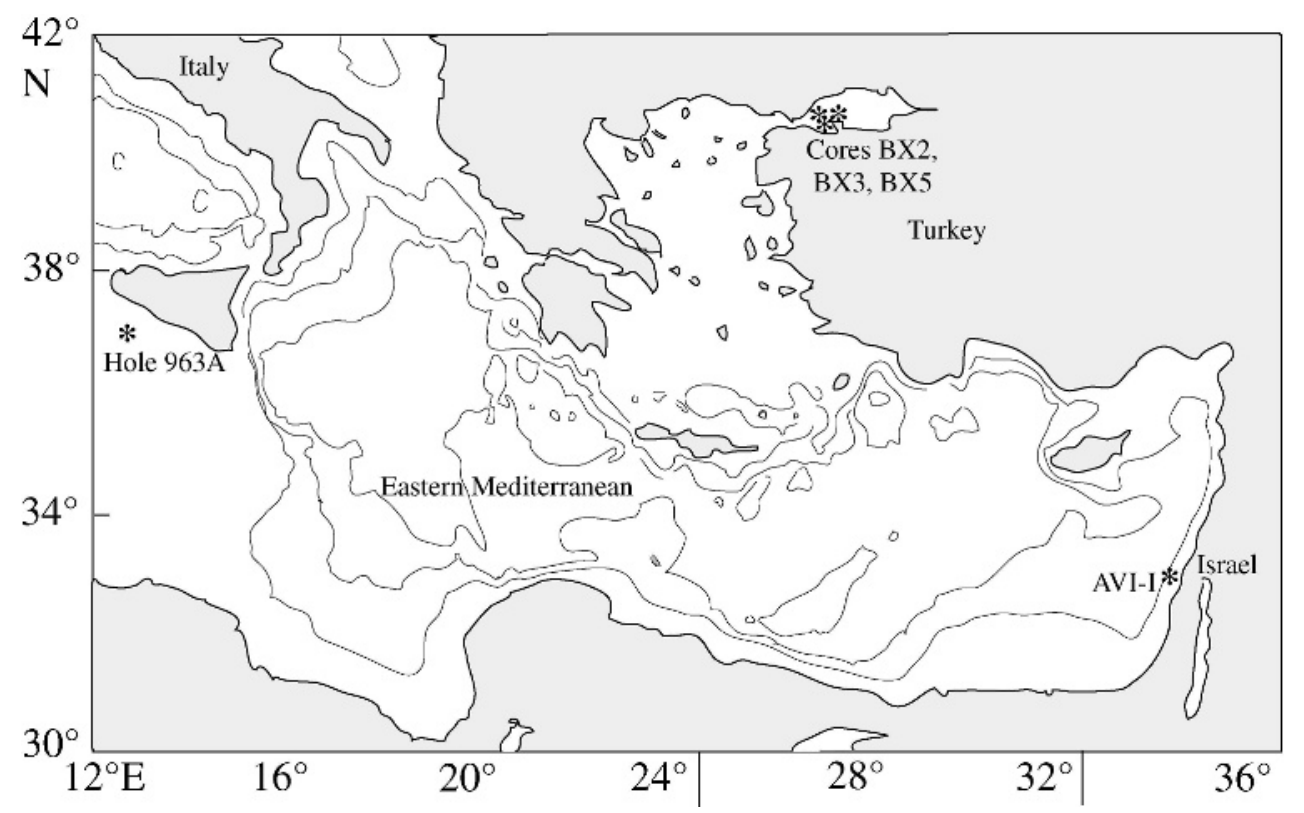

FIGURE 1. Map of the Eastern Mediterranean Sea showing the location of ODP Hole 160-963A (Southern Sicily); AVI-I (Israeli coast); and Cores BX2, BX3 and BX5 (Sea of Marmara) where Hyalinea balthica and H. marmarica were found. Figure modified after Spezzaferri and others (1998).

each slab was soaked and washed in distilled water, and dried at room temperature - no floatation techniques were employed. Dried samples were then split, and about 300 foraminifera were picked and counted, whenever possible, for population statistics as described in Yanko-Hombach and others (2006). (3) Four stations were sampled along the Israeli coast (Fig. 1, Table 1) as part of the AVIECENNE Project (AVICENNE Annual Report, 1993; 1995; 1996). The samples from the Israeli shelf were recovered by box corer (BX 700 AI Compact Box Corer) in May 1993 by the $\mathrm{R} / \mathrm{V}$ Shikmona. Samples for foraminiferal analysis were collected onboard from the uppermost $2 \mathrm{~cm}$ of the sediment column with the aid of a wooden spatula, and treated in a $4 \%$ formalin solution made with seawater buffered by $20 \mathrm{~g}$ of $\mathrm{Na}_{2} \mathrm{~B}_{4} \mathrm{O}_{7}$ per liter. The number of living (rose Bengal stained) foraminifera was calculated in wet sediment samples equal to $5 \mathrm{~g}$ of dry sediment. When the abundance of benthic foraminifera was low, whole samples were counted. If the number of live specimens was small at a given station (50-100 specimens per $5 \mathrm{~g}$ sediment), foraminiferal analysis was repeated on five different aliquots of sediment for each sample, and the mean of the five replicates was used (Yanko and others, 1998).

Radiocarbon ages in conventional ${ }^{14} \mathrm{C}$ years, without a reservoir correction or further calibration, were obtained for the samples from the Sea of Marmara (Table 2).

TABLE 1. Coordinates, water depth and core length of cores from the Sea of Marmara.

\begin{tabular}{lcccc}
\hline Box core & $\begin{array}{c}\text { Latitude } \\
(\mathrm{N})\end{array}$ & $\begin{array}{c}\text { Longitude } \\
(\mathrm{E})\end{array}$ & $\begin{array}{c}\text { Water depth } \\
(\mathrm{m})\end{array}$ & $\begin{array}{c}\text { Core length } \\
(\mathrm{cm})\end{array}$ \\
\hline BX-2 & $40^{\circ} 54.48^{\prime}$ & $28^{\circ} 56.03^{\prime}$ & 64 & 48.0 \\
BX-3 & $40^{\circ} 49.48^{\prime}$ & $27^{\circ} 57.35^{\prime}$ & 1226 & 50.0 \\
BX-5 & $40^{\circ} 32.02^{\prime}$ & $27^{\circ} 09.37^{\prime}$ & 65 & 45.5 \\
\hline
\end{tabular}

Measurements were made at the Quaternary Dating Research Unit, CSIRO, Pretoria, South Africa using the conventional beta particle counting technique. The bulk carbonate (consistently $30 \%$ of the sediment) from the $2-\mathrm{cm}$ slices of the cores was dried, microscopically analyzed, and treated with hydrochloric acid to release carbon dioxide, which was used for radiometric analysis in a gas proportional counter as described in Yanko-Hombach and others (2006).

Electron scanning microscope (SEM) images were obtained with a FEI XL30 Sirion FEG microscope. Specimens were mounted on an SEM sample holder, coated with 40 nanometers of gold and observed and imaged using a standard beam voltage of $20 \mathrm{kV}$ at a probe current of $15 \mathrm{nA}$.

\section{SYSTEMATIC PALEONTOLOGY}

Only six specimens of Hyalinea balthica were found in the four AVI-I sites. In contrast, both $H$. balthica and $H$. marmarica were relatively abundant in the three cores from the Sea of Marmara from the surface to $37 \mathrm{~cm}, 50 \mathrm{~cm}$ and $45 \mathrm{~cm}$ in Cores BX2, BX3 and BX5, respectively (Table 3). $H$. balthica was abundant in the sedimentary sequence from ODP Hole 160-963A, from 200-120 meters below sea floor (mbsf) and from 30-10 mbsf. These sediments were de-

TABLE 2. Uncalibrated radiocarbon age of sediment samples from cores of the Sea of Marmara.

\begin{tabular}{|c|c|c|c|}
\hline Core & Sampling depth & $\begin{array}{c}{ }^{14} \mathrm{C} \text { age (in conventional years, } \\
\text { without reservoir correction } \\
\text { or further calibration) }\end{array}$ & ID number \\
\hline $\mathrm{BX} 2$ & $3-6.5 \mathrm{~cm}$ & $6160 \pm 120 \delta 13 \mathrm{C}=-1.3 \%$ & Pta-6880 \\
\hline BX-2 & $43-48 \mathrm{~cm}$ & $7030 \pm 100 \delta 13 \mathrm{C}=-0.9 \%$ & Pta-6870 \\
\hline BX-3 & $48-50 \mathrm{~cm}$ & $5550 \pm 120 \delta 13 \mathrm{C}=-2.4 \%$ & Pta-6868 \\
\hline
\end{tabular}


TABLE 3. Number of specimens of Hyalinea balthica and H. marmarica in Cores BX2, BX3 and BX5 (Sea of Marmara) and total abundance of benthic foraminifera in each sample.

\begin{tabular}{|c|c|c|c|c|c|c|c|c|c|c|}
\hline \multicolumn{4}{|c|}{ Core BX2 } & \multicolumn{3}{|c|}{ Core BX3 } & \multicolumn{4}{|c|}{ Core BX5 } \\
\hline $\begin{array}{l}\text { Depth } \\
\text { (cm) }\end{array}$ & $\begin{array}{l}\text { Specimens } \\
\text { of } H \text {. } \\
\text { balthica }\end{array}$ & $\begin{array}{c}\text { Specimens of } \\
H . \\
\text { marmarica }\end{array}$ & $\begin{array}{l}\text { Total benthic } \\
\text { foraminifera }\end{array}$ & $\begin{array}{l}\text { Depth } \\
\text { (cm) }\end{array}$ & $\begin{array}{l}\text { Specimens } \\
\text { of } H . \\
\text { balthica }\end{array}$ & $\begin{array}{l}\text { Total benthic } \\
\text { foraminifera }\end{array}$ & $\begin{array}{l}\text { Depth } \\
\text { (cm) }\end{array}$ & $\begin{array}{l}\text { Specimens } \\
\text { of } H \text {. } \\
\text { balthica }\end{array}$ & $\begin{array}{l}\text { Specimens of } \\
\text { H. marmarica }\end{array}$ & $\begin{array}{l}\text { Total benthic } \\
\text { foraminifera }\end{array}$ \\
\hline $0.0-3.0$ & 0 & 1 & 126 & $0.0-3.0$ & 0 & 79 & $0.0-2.0$ & 5 & 9 & 421 \\
\hline $3.0-6.5$ & 4 & 1 & 264 & $3.0-11.0$ & 0 & 115 & $2.0-10.0$ & 5 & 2 & 194 \\
\hline $6.5-10.0$ & 0 & 8 & 279 & $11.0-14.0$ & 0 & 34 & $10.0-12.0$ & 0 & 17 & 244 \\
\hline $10.0-13.0$ & 0 & 5 & 255 & $14.0-20.0$ & 0 & 110 & $12.0-20.0$ & 1 & 6 & 224 \\
\hline $13.0-16.0$ & 1 & 13 & 294 & $20.0-24.0$ & 0 & 180 & $20.0-22.0$ & 3 & 20 & 296 \\
\hline $16.0-19.0$ & 2 & 14 & 316 & $24.0-27.0$ & 1 & 234 & $22.0-26.0$ & 6 & 12 & 228 \\
\hline $19.0-22.0$ & 1 & 6 & 316 & $27.0-30.0$ & 1 & 118 & $26.0-30.0$ & 8 & 0 & 162 \\
\hline $22.0-25.0$ & 1 & 4 & 320 & $30.0-34.0$ & 0 & 92 & $30.0-33.0$ & 3 & 11 & 180 \\
\hline $25.0-28.0$ & 2 & 4 & 263 & $34.0-37.0$ & 0 & 139 & $33.0-37.0$ & 3 & 12 & 178 \\
\hline $28.0-31.0$ & 2 & 0 & 270 & $37.0-42.0$ & 0 & 165 & $37.0-40.0$ & 5 & 10 & 185 \\
\hline $31.0-34.0$ & 1 & 0 & 271 & $42.0-50.0$ & 1 & 64 & $40.0-42.0$ & 3 & 16 & 168 \\
\hline $34.0-37.0$ & 1 & 4 & 256 & no samples & - & - & $42.0-45.0$ & 4 & 15 & 174 \\
\hline
\end{tabular}

posited from 1.5 Ma to $\sim 0.7 \mathrm{Ma}$ and from $0.26 \mathrm{Ma}$ to the uppermost Pleistocene, respectively (Robertson and others, 1996). A morphological study of the different specimens of H. balthica and their spatial and temporal distribution has enabled the identification of two stable morphologies described and distinguished below.

\section{Hyalinea balthica (Schröter)}

Pl. 1, figs. 1, 3a-b; Pl. 2, figs. 2a-c, $4 \mathrm{a}-\mathrm{b}, 5 \mathrm{a}-\mathrm{c}$

1783 Nautilus balthicus Schröter in Schröter; p. 20, pl. 1, fig. 2. 1791 Nautilus balthicus Schröter in Gmelin in Linnaeus 1791, p. 3370. 1971 Hyalinea balthica (Schröter) in Murray, p. 173, Pl. 72, figs. 5-7. 1986 Hyalinea balthica (Schröter) in van Mokhaven and others, Pl. 3, figs. $1-3$.

2003 Hyalinea balthica (Schröter) in Murray, Pl. 8, figs. 8-10.

2004 Hyalinea balthica (Schröter) in Meriç and others, Pl. 27, fig. 3.

Repository. Not given.

Diagnosis. This species includes forms resembling the syntype from the Baltic Sea (Pl. 1, fig. 1). Test size is variable, ranging from 125 $250 \mu \mathrm{m}$. Chamber arrangement is planispiral or slightly trochospiral, with chambers slowly increasing in size as added. Nine to twelve chambers are present in the last whorl and are generally ovate to subtriangular, the peripheral margin is rounded to slightly subacute and the test outline is circular. A keel is always present and strongly marked. The aperture is an extraumbilical, interiomarginal low arch, bordered by a distinct but thin lip. Sutures are straight to arched, strongly limbate and merging with the peripheral keel. The characteristic secondary apertures beneath the umbilical flap are present on both sides of the test.

Remarks. In ODP Hole 160-963A, two forms co-occur: a form that closely resembles the syntype (Pl. 1, figs. 3a-b) and morphotypes that display more inflated chambers and less marked and slightly depressed sutures ( $\mathrm{Pl}$. 2, figs. 3a-b). The latter forms resemble the Pliocene specimens from the Arabian Sea that were described by Hermelin (1991) as possessing less limbate sutures and less pronounced keels with respect to upper Pliocene and Pleistocene specimens and which he considered a subspecific group of Hyalinea balthica.

Ross (1984) provided a good record from the Strait of Sicily of different morphotypes that he considered related to climatic factors. He attributed massive and thick morphologies with strongly limbate sutures and a distinct keel to glacial stages. Accordingly, he attributed more delicate morphotypes with more inflated chambers, a lobate profile, and less thickened (limbate) sutures to the Marine Isotope Stage (MIS) 5e. The rare delicate forms morphologically grading into the thicker ones were described as ecophenotypes. These gradational morphotypes and the delicate forms, similar to those described by Ross (1984) in the Strait of Sicily, were not observed at ODP Hole 160-963A.
However, the levels containing these specimens could have been missed during sampling.

Hyalinea marmarica $\mathrm{n}$. sp.

Pl. 1, figs. 2a-e, 4a-d; Pl. 2, figs. 1a-c

1984 Hyalinea balthica (Schröter) sensu Ross (non Schröter, 1783) in Ross, Pl. 1, figs. 14-16.

2002 Hyalinea balthica (Schröter) sensu Kaminski and others (non Schröter, 1783) in Kaminski and others, Pl. 3, fig. 13.

2004 Hyalinea balthica (Schröter) sensu Chendler and others (non Schröter, 1783) in Chendler and others, Pl. 3, fig. 1a-b.

Holotype specimens. Illustrated in Pl. 1, fig. 2a-e.

Derivation of the name. From the Sea of Marmara.

Type level. Sample BX2, $13-16 \mathrm{~cm}$.

Type section. Core BX2 retrieved in the Sea of Marmara, at $64 \mathrm{~m}$ water depth, Lat. $40^{\circ} 54.48^{\prime} \mathrm{N}$; Long. $28^{\circ} 56.03^{\prime} \mathrm{E}$.

Age available. Between $6160 \mathrm{yr}$ BP (measured at $3 \mathrm{~cm}$ depth in core) and $7030 \mathrm{yr} \mathrm{BP}$ (measured at $48 \mathrm{~cm}$ depth in core). The total stratigraphic range of this species is presently not known.

Sediment lithology. Homogeneous gray mud.

Repository. Natural History Museum of Basel, Switzerland. Ref. C39018. The paratypes (Pl. 1, figs. 4a-d; Pl. 2, figs. 1a-c) are deposited in the AVICENNE collection stored in the Avalon Institute of Applied Science, Winnipeg, Canada.

Diagnosis. Test size is variable and averages from $200-250 \mu \mathrm{m}$ in maximum diameter. Chamber arrangement is planispiral or slightly trochospiral, with chambers moderately increasing in size as added. A maximum of eight chambers is present in the last whorl. They are, generally, strongly subtriangular, the test outline is lobate and the peripheral margin is always subacute. A keel is sometimes present, especially in the inner chambers of the last whorl, but very weakly developed. The aperture is an extraumbilical, interiomarginal low arch, bordered by a distinct but thin lip. Sutures are strongly sigmoidal, depressed in the last four chambers of the last whorl and slightly limbate in the remaining four chambers. The characteristic secondary apertures beneath the umbilical flap are present on both sides of the test. The flaps are generally well developed. The wall texture displays slightly smaller and denser pores than in Hyalinea balthica (Pl. 2, figs. $1 \mathrm{~d}, 5 \mathrm{c})$. Supplementary apertures are often present along the peripheral margin in sutural position ( $\mathrm{Pl}$. 1, figs. $2 \mathrm{~d}-\mathrm{e}, 4 \mathrm{~d}$; Pl. 2, fig. 1c).

Remarks. Hyalinea marmarica is relatively abundant in Cores BX2 and BX5. Table 3 shows its abundance with respect to the total abundance of benthic foraminifera.

This species differs from Hyalinea balthica in having a maximum of eight chambers in the last whorl, depressed sutures at least in the four last chambers, a moderate increase in chamber size as added, a subacute profile and accessory apertures on the peripheral margin.

It differs from the early Pliocene forms described by Hermelin (1991) in having eight chambers in the last whorl instead of nine to ten, 
a subacute profile and less inflated chambers. It differs from the interglacial related morphotypes of Hyalinea balthica described by Ross (1984) in having less numerous chambers in the last whorl (eight instead of nine to ten), less limbate sutures and less inflated chambers.

It differs from Hyalinea inflata, described by Ujiie and Kusukava (1969), in having a subacute and slightly keeled peripheral margin, eight chambers in the last whorl, sigmoidal sutures and supplementary apertures along the peripheral margin, instead of a rounded, nonkeeled peripheral margin, six chambers in the last whorl, curved sutures and lacking a supplementary aperture along the peripheral margin.

\section{DISCUSSION}

In biology, the presence of specimens displaying a certain morphology grading into another morphology within the same assemblage is generally interpreted as species variability within a taxon (e.g., Simpson, 1961, p. 150-153). Additionally, the presence of specimens displaying a certain morphology grading into another morphology across an ecological gradient is generally interpreted as ecophenotypic variation. Accordingly, Ross (1984) interpreted the delicate forms of Hyalinea balthica, which are present in interglacial MIS 5e, as ecophenotypes of the typical $H$. balthica that is present in glacial stages, because he observed rare morphological gradation between the two forms. Following Ross's (1984) observations, H. balthica has always been considered a species with high intraspecific variability. Transitional specimens were not observed in the samples investigated from the Sea of Marmara. On the contrary, within the same assemblages, very rare specimens of $H$. balthica similar to the syntype (Pl. 2, figs. 2a-c) coexist with $H$. marmarica, without gradational morphologies between the two forms.

\section{Autecology of HyALINEA BALTHICA AND H. MARMARICA}

In the following sections, the ecological preferences of Hyalinea balthica in terms of salinity, dissolved oxygen and temperature are compared with those of $H$. marmarica. Table 4 shows the average values of these parameters at the sea floor and at $400-500 \mathrm{~m}$ water depth in the Sea of Marmara, the Eastern Mediterranean Sea and the North Atlantic Ocean, respectively.

According to the existing literature, Hyalinea balthica is an epifaunal species living within the first $0.5 \mathrm{~cm}$ of sediments (Murray, 2003) between 50-4000 m water depth (e.g., Cita and others, 1977). In the Atlantic Ocean and Mediterranean Sea, the greatest abundance of this species is found between 400-500 $\mathrm{m}$ depth (Blanc-Vernet, 1969; Colom, 1974; Cita and others, 1977; de Rijk and others, 1999; Meriç and others, 2004).

In the North Atlantic Ocean (e.g., in the northwest European shelf seas), Hyalinea balthica lives in environments where bottom temperature is $\sim 4{ }^{\circ} \mathrm{C}$ in winter and $\sim 7.5^{\circ} \mathrm{C}$ in summer (Elliott and others, 1991; Murray, 2003;
Norman, 2001; Husum and Hald, 2004), and mean bottom salinities are $\sim 34.0-35.0$ psu (Murray, 2003). At the preferred depth of this species $(400-500 \mathrm{~m})$, bottom temperature reaches $7.5^{\circ} \mathrm{C}$, salinity is constantly $\sim 34.0-35.0 \mathrm{psu}$ and oxygen content is variable depending on local factors (Table 4).

In the Mediterranean Sea, at the preferred depth of this species $(300-500 \mathrm{~m})$, bottom temperature reaches 14.5$15^{\circ} \mathrm{C}$ and salinity is $\sim 38-39$ psu (POEM Group, 1992). Dissolved oxygen content does not vary from 400-500 down to the sea floor and displays values of $\sim 4.2-4.4 \mathrm{ml} / 1$ (Table 4; Roether and Well, 2001).

In the Sea of Marmara, rare specimens of Hyalinea balthica have been found at water depth of 64 and $65 \mathrm{~m}$ (Core BX2 and BX5, respectively), and at $111 \mathrm{~m}$ (Kaminski and others, 2002). Core BX3, retrieved at a water depth of $1226 \mathrm{~m}$, contains only very rare specimens (Table 3 ). In this basin, bottom salinity is presently $\sim 38$ psu (e.g., Chendes and others, 2004). Direct measurement of water temperature from $50-500 \mathrm{~m}$ gives values consistently near $18^{\circ} \mathrm{C}$ (Chendes and others, 2004). No direct measurements are available for bottom temperature. Oxygen content decreases from $2 \mathrm{ml} / 1$ at about $65 \mathrm{~m}$ to $1.1 \mathrm{ml} / 1$ at the sea floor (Chendes and others, 2004).

The biogeography and the habitat of foraminiferal taxa can be satisfactorily determined only from direct observation of living individuals (Murray, 2003). However, because living specimens of Hyalinea marmarica have not been observed in the studied material, the comparison between the ecological preferences of the two species must be complemented by the examination of the ecological preferences of $H$. balthica in the past.

Rich Hyalinea balthica assemblages, dated from 7600 $5700 \mathrm{yr}$ BP, have been found in northern Norway. These paleoenvironments are characterized by a water depth of about $450 \mathrm{~m}$ and bottom temperatures derived from oxygen isotopes of $\sim 6-11^{\circ} \mathrm{C}$ (Husum and Hald, 2004), indicating ecological preferences similar to those of living specimens from the northwest European shelf seas and not far from those of living specimens in the Mediterranean Sea. Moreover, the paleoceanographic reconstruction made by Aksu and others (2002) for the Sea of Marmara in the interval between 6000-7000 yr BP reveals that salinity and temperature in the area did not sensibly differ from those of the present.

In summary, the interpretation of the ecological preference of Hyalinea marmarica is based on the ecological preferences of living and fossils $H$. balthica, and on the ecological parameters summarized in Table 4. In particular, $H$. marmarica is interpreted to be tolerant of a wider range of temperatures with respect to $H$. balthica and perhaps has a higher optimal temperature $\left(\sim 18^{\circ} \mathrm{C}\right)$. It is less tolerant

$\leftarrow$

between the fifth and the sixth chamber of the last whorl located along the peripheral margin. In the holotype, these supplementary apertures are not strongly developed. Sample BX2, 13-16 cm. 3a,b Hyalinea balthica (Schröter): 3a lateral view; 3b side view, this specimens resemble the holotype of figure 1, with numerous chambers in the last whorl and strongly marked sutures; ODP Sample 160-963A-22H-CC. 4a-d Hyalinea marmarica Spezzaferri and Yanko-Hombach: 4a lateral view; $4 \mathbf{b}$ side view; 4c lateral view; $4 \mathbf{d}$ details of the supplementary apertures along the peripheral margin; Sample BX5, 0-2 cm. 
TABLE 4. Ecological parameters (salinity, dissolved oxygen and temperature) in the Sea of Marmara, Eastern Mediterranean Sea and North Atlantic Ocean at the sea floor and at 400-500 m. Data compiled from the POEM Group (1992); Roether and Well (2001); Normann (2001); Özsoy and others (1995); Husum and Had (2003); Murray (2003); Falkner and others (2005); Chandes and others (2004); Mudie and others (2004). NA = not available.

\begin{tabular}{lccc}
\hline \multicolumn{1}{c}{ Parameter } & Sea of Marmara & Eastern Mediterranean Sea & North Atlantic Ocean \\
\hline Salinity in psu (bottom) & $38.8-38.6$ & Variable from 38 to hypersaline & $34-35$ \\
Salinity in psu (400-500 m) & $38.8-38.6$ & $38.5-39$ & $34-35$ \\
Oxygen in ml/l (bottom) & dysoxic & $4.2-4.4$ & Variable \\
Oxygen in $\mathrm{ml} / \mathrm{l}(400-500 \mathrm{~m})$ & Lower than 1.1 & 4.2 & Variable \\
Temperature in ${ }^{\circ} \mathrm{C}($ bottom) & N.A. but lower than 18 & $4-10$ & 4 \\
Temperature in ${ }^{\circ} \mathrm{C}(400-500 \mathrm{~m})$ & About 18 & $14-14.5$ & $7-10$ \\
\hline
\end{tabular}

with respect to variation in salinity than $H$. balthica, which can live in water with salinity ranging from $34-39$ psu in both the Atlantic Ocean and Eastern Mediterranean Sea.

The presence of Hyalinea marmarica and H. balthica in sediments retrieved from a water depth of $65 \mathrm{~m}$, where dissolved oxygen is $\sim 1.8-2.0 \mathrm{ml} / \mathrm{l}$, and the presence of $H$. balthica, even if rare, in the absence of $H$. marmarica in deeper water (Core BX3), where dissolved oxygen is $<1.1 \mathrm{ml} / 1$ (Chendes and other, 2004), suggest that $H$. balthica is more tolerant of a low level of dissolved oxygen than is $H$. marmarica. The absence of $H$. marmarica in Core $\mathrm{BX} 3$, retrieved at a water depth of $1226 \mathrm{~m}$, and its common occurrence at $64-65 \mathrm{~m}$ might suggest that this species prefers shallower waters than $H$. balthica. However, further sampling and studies are needed to confirm the depth and ecological preference of $H$. marmarica.

\section{PALEOCEANOGRAPHIC IMPLICATIONS}

In the eastern Mediterranean Sea, the abundance of Hyalinea balthica is variable (Ross, 1984), and its presence through the Quaternary is discontinuous (Lourens and others, 1998), reflecting environmental and climatic changes (e.g., Robertson and others, 1996). This species has been present in the Mediterranean Sea for 1.58 m.y. (e.g., Vaiani, 2000), and its appearance in the basin coincides with the ingression of cold-water, North Atlantic species into the Mediterranean Sea.

For the last $\sim 1.4$ m.y., the Mediterranean Sea, like the global oceans, has been under the influence of glacialinterglacial climate oscillations. The early to late Pleistocene $\delta^{18} \mathrm{O}$ record of ODP Site 160-963 indicates that major climatic cooling occurred at approximately 0.98 and $0.45 \mathrm{Ma}$ (Howell and others, 1998). These cooling episodes were optimal for the proliferation and life of Hyalinea balthica, as suggested by its abundance in samples from ODP Hole 160-963A (Robertson and others, 1996). Interglacial times probably were not conducive to the proliferation of this species.

The latest post-glacial sea level rise started at about $14 \mathrm{ka}$ in the Eastern Mediterranean region (Chappel and Shack- leton, 1986; Fairbanks, 1989). Probably from 14 to $12 \mathrm{ka}$, increasingly efficient connections between the Sea of Marmara (bedrock sill depth of the Dardanelles Strait is $70 \mathrm{~m})$ and the Eastern Mediterranean Sea were progressively established (e.g., Kaminski and others, 2002). It can be proposed that the migration of Hyalinea balthica into the Sea of Marmara occurred at this time. Some specimens of $H$. balthica possibly entered the Sea of Marmara through the Dardanelle Strait. In the Sea of Marmara, they might have modified their morphology in response to the extreme environmental conditions, giving rise to $H$. marmarica and leaving robust forms of $H$. balthica as a minor component of the assemblages (Fig. 2).

\section{CONCLUSIONS}

The benthic foraminifera Hyalinea balthica is a species with great morphological variability. The morphological adaptations of $H$. balthica found in the Mediterranean Sea have been related to climatic changes. Since its Pleistocene ingression into the Mediterranean Sea at $1.58 \mathrm{Ma}$, this species has been subject to periodic, climate-driven modifications. In the Sea of Marmara, these modifications ultimately gave rise to stable morphologies that differ from those of the syntype. The comparison of these specimens to those similar to the holotype has allowed the distinction and codification of the criteria for the identification of the species $H$. balthica. The documentation of these different morphologies leads to the proposal of the species, Hyalinea marmarica n. sp., as an example of environment-related speciation.

\section{ACKNOWLEDGMENTS}

The first author thanks the Ocean Drilling Program for inviting her to sail onboard ODP Leg 160 to the Eastern Mediterranean Sea. The second author thanks Professors Orhan Uslu and M. Kazim Duzbastilar of Dohuz Eylul University for providing the cores from the Sea of Marmara, and Dr. J. C. Vogel for performing the radiocarbon analysis. The photographic documentation of

$\leftarrow$

Sample BX5, 0-2 cm. 3a,b Hyalinea balthica (Schröter): 3a lateral view, 3b side view. This specimen has a more rounded peripheral margin and less developed keel than specimens typical of this species and the two forms are found together in the same assemblage. ODP Sample 160-963A-22H-CC. 4a,b Hyalinea balthica (Schröter), 4a lateral view, 4b side view. Typical specimen from ODP Sample 160-963A-22H-CC. 5a-c Hyalinea balthica (Schröter), typical specimen from ODP Sample 160-963A-22H-CC. 5a lateral view, 5b side view, 5c detail of the wall texture showing less dense and slightly larger pores than in H. marmarica. 
Hyalinea balthica and $H$. marmarica has been obtained with the SEM of the University of Fribourg, and we warmly thank C. Neururer for his assistance. A warm thank goes to Richard Waite for his correction of the English form. The comments of C. Brunner, R. Fleisher and M.-T. VenecPeyré greatly improved the manuscript.

\section{REFERENCES}

Aksu, A. E., Hiscott, R. N., Kaminski, M. A., Mudie, P. J., Gillespie, T., Abrajano, T., and Yasar, D., 2002, Last GlacialHolocene palaeoceanography of the Black Sea and Marmara Sea: stable isotopic, foraminiferal and coccolith evidence: Marine Geology, v. 190, p. 119-149.

Ariztegui, D., Asioli, A., Lowe, J. J., Trincardi, F., Tamburini, F., Accorsi, C. A., Bandini Mazzanti, M., Mercuri, A. M., Van der Kaars, S., Chondrogianni, C., McKenzie, J. A., and OLDFIELD, F., 2000, Palaeoclimatic reconstructions and formation of sapropel S1: inferences from Late Quaternary lacustrine and marine sequences in the central Mediterranean region: Palaeogeography, Palaeoclimatology, Palaeoecology, v. 158 , no. 3-4, p. $215-240$.

Avicenne Annual Report, 1993, Benthic Foraminifera as Indicators of Heavy Metal Pollution-A New Kind of Biological Monitoring for the Mediterranean Sea. Contract Number AVI CT92-0007, $41 \mathrm{p}$.

, 1995, Benthic Foraminifera as Indicators of Heavy Metal Pollution-A New Kind of Biological Monitoring for the Mediterranean Sea. Contract Number AVI CT92-0007, 270 p.

, 1996, Benthic Foraminifera as Indicators of Heavy Metal Pollution-A New Kind of Biological Monitoring for the Mediterranean Sea. Contract Number AVI CT92-0007, 167 p.

Blanc-Vernet, L., 1969, Contribution à l'étude des foraminifères de Méditerranée: Recueil des Travaux de la Station Marine d'Endume, v. 64 , no. 48 , p. 1-281.

Bock, W. D., 1970, Hyalinea balthica and the Plio-Pleistocene boundary in the Caribbean Sea: Science, v. 170, p. 847-848.

Bremer, M. L., Briskin, M., and Berggren, W. A., 1980, Quantitative paleobathymetry and paleoecology of the Late Pliocene early Pleistocene foraminifera of Le Castella (Calabria, Italy): Journal of Foraminiferal Research, v. 10, no. 1, p. 1-30.

Chappel, J., and Shackleton, N. J., 1986, Oxygen isotopes and sea level: Nature, v. 324, p. 137-140.

Chendes, C., Kamisnki, M. A., Filipescu, S., Aksu, A. E., and YASAR, D., 2004, The response of modern benthic foraminiferal assemblages to water-mass properties along the southern shelf of the Marmara Sea: Acta Palaeontologica Romaniae, v. 4, p. 69-80.

Cita, M. B., Vergnaud-Grazzini, C., Robert, C., Chamley, H., Ciaranfi, N., and D'Onofio, S., 1977, Paleoclimatic record of a long deep sea core from the eastern Mediterranean: Quaternary Research, v. 8, p. 205-235.

Colom, G., 1974, Foraminiferos Ibéricos: introduccion al estudio de las especias bentonicas recientes: Investigatione Pesquera, v. 5, p. $59-68$

Comas, M. C., Zahn, R., and Klaus, A. (eds.), 1996, Proceedings of the Ocean Drilling Program, Scientific Results, v. 161: Ocean Drilling Program, College Station, TX, 607 p.

de Rijk, S., Troelstra, S. R., and Rohling, E. J., 1999, Benthic foraminiferal distribution in the Mediterranean Sea: Journal of Foraminiferal Research, v. 29, no. 2, p. 93-103.

Elliott, A. J., Clarke, T., and Li, Z., 1991, Monthly distributions of surface and bottom temperatures in the northwest European shelf seas: Continental Shelf Research, v. 11, p. 453-466.

Emeis, K.-C., Struck, U., Schulz, H.-M., Rosenberg, R., BernasConi, S., Erlenkauser, H., Sakamoto, T., and Martinez-Ruiz, T., 2000, Temperature and salinity variations of Mediterranean Sea surface waters over the last 16.000 years from records of planktonic stable oxygen isotopes and alkenone unsaturation ratios: Palaeogeography, Palaeoclimatology, Palaeoecology, v. 158 , p. $259-280$.

Emiliani, C., Mayeda, T., and Selli, R., 1961, Paleotemperature analysis of the Plio-Pleistocene section at Le Castella, Calabria, southern Italy: Geological Society of America Bulletin, v. 72, p. $679-688$.

FAIRBANKS, R. G., 1989, A 17,000 years glacioeustatic sea level record: influence of glacial melting rates on the Younger Dryas event and deep ocean circulation: Nature, v. 342, p. 637-642.

Falkner, K. K., Steeleb, M., Woodgateb, R. A., Swift, J. H., AagAardB, K., and Morison, J., 2005, Dissolved oxygen extrema in the Arctic Ocean halocline from the North Pole to the Lincoln Sea: Deep Sea Research I, v. 52, p. 1138-1154.

Flint, R. F., 1965, The Plio-Pleistocene boundary, in Wright, H. E., Jr., and Frey, D. G. (eds.), International Studies on the Quaternary: Geological Society of America Special Paper 84, p. 497-533.

Gignoux, M., 1910, Sur la classification du Pliocene et du Quaternaire dans l'Italie du Sud: Comptes Rendus de l'Academie des Sciences, v. 150 , p. $841-844$.

Hermelin, J. O., 1991, Hyalinea balthica (Schroeter) in Lower Pliocene sediments of the Northwest Arabian Sea: Journal of Foraminiferal Research, v. 21, no. 3, p. 244-251.

Howell, M. W., Thunell, R. C., Di Stefano, E., Sprovieri, R., TAPPA, J., and SAKAмото, T., 1998, Stable isotopes chronology and paleoceanographic history of Sites 963 and 964, Eastern Mediterranean Sea, in Robertson, A. H. F., Emeis, K.-C., Richter, C., and Camerlenghi, A. (eds.), Proceedings of the Ocean Drilling Program, Scientific Results, v. 160: Ocean Drilling Program, College Station, TX, p. 167-180.

Husum, K., and Hald, M., 2004, A continuous marine record 8000$1600 \mathrm{cal}$. yr BP from Malangenfjord, north Norway: foraminiferal and isotopic evidence: The Holocene, v. 14, p. 878-887.

Kaminski, M. A., Aksu, A., Box, M., Hiscott, R. N., Filipescu, S. and Al-Salameen, M., 2002, Late Glacial to Holocene benthic foraminifera in the Marmara Sea: implication for Black SeaMediterranean Sea connections following the last deglaciation: Marine Geology, v. 190, p. 165-202.

Linnaeus, C., 1791, Systema Naturae, Leipzig, 13th edition: G. E. Beer, Leipzig, v. 1, pt. 6, p. 3370.

Lourens, L. J., Hilgen, F. J., and Raffi, I., 1998, Base of large Gephyrocapsa and astronomical calibration of Early Pleistocene sapropels in Site 967 and Hole 969D: solving the chronology of the Vrica Section (Calabria, Italy), in Robertson, A. H. F., Emeis, K.-C., Richter, C., and Camerlenghi, A. (eds.), Proceedings of the Ocean Drilling Program, Scientific Results, v. 160: Ocean Drilling Program, College Station, TX, p. 191-197.

Meriç, E., Avsar, N., and Bergin, F., 2004, Benthic Foraminifera of Eastern Aegean Sea (Turkey) Systematic and Autoecology, Turkish Marine Research Foundation, Istanbul, Turkey, Pub. No. 18,306 p.

Mudie, P. J., Rochon, A., Aksu, A. E., and Gillespie, H., 2004, Late glacial, Holocene and modern dinoflagellate cyst assemblages in the Aegean-Marmara-Black Sea corridor: statistical analysis and re-interpretation of the early Holocene Noah's Flood hypothesis: Review of Palaeobotany and Palynology, v. 128, p. 143-167.

Murray, J. W., 1971, An Atlas of British Recent Foraminiferids: Heinemann Educational Books, London, 244 p.

, 2003, An illustrated guide to the benthic foraminifera of the Hebridean Shelf, west of Scotland, with notes on their mode of life: Palaeontologia Electronica, v. 5, no. 1, 31 p., <http:// palaeoelectronica.org/paleo/2002_2/guide/issue2_02.htm $>$.

Özsoy, E., Latif, M. A., Tugrul, S., and Ünluata, U., 1995, Exchanges with the Mediterranean, fluxes, and boundary mixing processes in the Black Sea: Bulletin de l'Institut Océanographique de Monaco, v. 15, p. 1-25.

POEM Group, 1992, General circulation of the Eastern Mediterranean: Earth Science Review, v. 32, p. 285-309.

Robertson, A., Emeis, K.-C., and Richter, C. (eds.), 1996, Proceedings of the Ocean Drilling Program, Initial Results, v. 160: Ocean Drilling Program, College Station, TX, 972 p. and CAmerlenghi, A. (eds.), 1998, Proceedings of the Ocean Drilling Program, Scientific Results, v. 160: Ocean Drilling Program, College Station, TX, 817 p.

Roether, W., and Well, R., 2001, Oxygen consumption in the Eastern Mediterranean: Deep-Sea Research I, v. 48, p. $1535-1551$. 
Ross, C. R., 1984, Hyalinea balthica and its Late Quaternary paleoclimatic implications: Strait of Sicily: Journal of Foraminiferal Research, v. 14, no. 2, p. 134-139.

SChröter, J. S., 1783, Einleitung in die Conchylienkenntniss nach Linné: Halle J. J., Gebaure, v. 1, 20 p.

SelLI, R., 1967, The Pliocene-Pleistocene boundary in Italian marine sections and its relationship to continental stratigraphies, in Sears, M. (ed.), The Quaternary History of the Ocean Basins, Progress in Oceanography, v. 4: Pergamon Press, New York, p. 67-86.

Simpson, G. G., 1961, Principles of Animal Taxonomy: Columbia University Press, New York, 247 p.

Spezzaferri, S., McKenzie, J. A., and Cita, M. B., 1998, The Miocene/Pliocene boundary in the Eastern Mediterranean: Results from ODP Leg 160, Sites 967 and 969, in Robertson, A. H. F., Emeis, K.-C., Richter, C., and Camerlenghi, A. (eds.), Proceedings of the Ocean Drilling Program, Scientific Results, v. 160: Ocean Drilling Program, College Station, TX, p. 9-28.

Ujiı́, H., and Kusukava, T., 1969, Analysis of foraminiferal assemblages from Miyako and Yamada Bays, northeastern Japan: Natural Science Museum Bulletin, Tokyo, v. 12, no. 3, p. 767-768.

van Morkhoven, F. P. C. M., Berggren, W. A., and Edwards, A. S., 1986, Cenozoic cosmopolithan deep-water benthic foraminifera: Bulletin des Centres de Recherches Exploration-Production Elf-Aquitaine, mem. 11, $421 \mathrm{p}$.

VAiani, S. C., 2000, Testing the applicability of strontium isotope stratigraphy in marine to deltaic Pleistocene deposits: an example from the Lamone River Valley (northern Italy): Journal of Geology, v. 108 , p. 585-599.

, and Venezia, P., 1999, Analisi quantitativa delle associazioni a foraminiferi bentonici e planctonici nella sezione pleistocenica del Lamone (Appennino romagnolo): Bollettino Società Paleontologica Italiana, v. 38, no. 1, p. 39-57.

Vergnaud-Grazzini, C., Ryan, W. B. F., and Cita, M. B., 1977, Stable isotopic fractionation, climate change and episodic stagnation in the Eastern Mediterranean during the late Quaternary: Marine Micropaleontology, v. 1, no. 2, p. 353-370.

Yanko, V., Ahmad, M., and Kaminski, M., 1998, Morphological deformities of benthic foraminiferal tests in response to pollution by heavy metals: implications for pollution monitoring: Journal of Foraminiferal Research, v. 28, no. 3, p. 177-200.

Yanko-Hombach, V., Koral, H., Avşar, N., Motnenko, I., and MCGANN, M., 2006, Geomorphological, depositional and foraminiferal indicators of Late Quaternary tectonic uplift in Iskenderun Bay, Turkey, in Dilek, Y., and Pavlides, S. (eds.), Postcollisional Tectonics and Magamatism in the Mediterranean Region and Asia: Geological Society of America Special Paper 409 , p. $591-614$. 